\title{
Measuring the Effects of Dollar Appreciation on Asia: A Favar Approach
}

\author{
Zheng Liu, Mark M. Spiegel, and Andrew Tai \\ Federal Reserve Bank of San Francisco
}

November 2016

Working Paper 2016-30

http://www.frbsf.org/economic-research/publications/working-papers/wp2016-30.pdf

\section{Suggested citation:}

Liu, Zheng, Mark M. Spiegel, Andrew Tai. 2016. "Measuring the Effects of Dollar Appreciation on Asia: A Favar Approach” Federal Reserve Bank of San Francisco Working Paper 2016-30. http://www.frbsf.org/economic-research/publications/working-papers/wp2016-30.pdf

The views in this paper are solely the responsibility of the authors and should not be interpreted as reflecting the views of the Federal Reserve Bank of San Francisco or the Board of Governors of the Federal Reserve System. 


\title{
MEASURING THE EFFECTS OF DOLLAR APPRECIATION ON ASIA: A FAVAR APPROACH
}

\author{
ZHENG LIU, \\ MARK M. SPIEGEL, \\ ANDREW TAI
}

\begin{abstract}
Exchange rate shocks have mixed effects on economic activity in both theory and empirical VAR models. In this paper, we extend the empirical literature by considering the implications of a positive shock to the U.S. dollar in a factor-augmented vector autoregression (FAVAR) model for the U.S. and three large Asian economies: Korea, Japan and China. The FAVAR framework allows us to represent a country's aggregate economic activity by a latent factor, generated from a broad set of underlying observable economic indicators. To control for global conditions, we also include in the FAVAR a "global conditions index," which is another latent factor generated from the economic indicators of major trading partners. We find that a dollar appreciation shock reduces economic activity and inflation not only for the U.S. economy, but also for all three Asian economies. This result, which is robust to a number of alternative specifications, suggests that in spite of their disparate economic structures and policy regimes, the dollar appreciation shock affects the Asian economies primarily through its impact on U.S. aggregate demand; and this demand channel dominates the expenditure-switching channel that affects a country's export competitiveness.
\end{abstract}

Date: November 14, 2016.

Key words and phrases. Monetary policy, real exchange Rate, FAVAR, United States, Korea, Japan, China, Asia.

JEL classification: C3; E4; E5, F33, F37, F42.

Liu: Federal Reserve Bank of San Francisco. Email: Zheng.Liu@sf.frb.org. Spiegel: Federal Reserve Bank of San Francisco. Email: Mark.Spiegel@sf.frb.org. Tai: Federal Reserve Bank of San Francisco. Email:Andrew.A.Tai@sf.frb.org. For helpful comments, we thank an anonymous referee, Joshua Aizenman, Pornpinun Chantapacdepong, Shin-Ichi Fukuda, Hiro Ito, Takatoshi Ito, Riyuzo Miyao, Kenichi Ueda, and participants at the JIMF University of Tokyo Conference on the Pacific Rim and the Global Economy. The views expressed in this paper are those of the authors and do not necessarily reflect the views of the Federal Reserve Bank of San Francisco or the Federal Reserve System. 


\section{INTRODUCTION}

Anticipation of U.S. monetary policy normalization led to significant appreciation of the dollar from mid-2014 to mid-2015. The dollar appreciation has raised concerns about potential spillover effects on economic activity of the trading partners of the United States.

In principle, a dollar appreciation should raise foreign net exports to the United States through an expenditure switching effect because it reduces the relative price of foreign goods sold in the U.S. market (Mendoza, 1995; Calderon et al., 2002). All else equal, this expenditure switching effect would be a drag on U.S. economic activity. ${ }^{1}$

In general, however, a dollar appreciation can have ambiguous effects on the economic activity of the trading partners of the United States. The ambiguity arises from the HarbergerLaursen-Metzler (HLM) effect. In particular, if a foreign currency depreciates against the dollar, the relative price of its exported goods falls and its terms of trade deteriorates. If the terms-of-trade deterioration is transitory, then domestic households would reduce savings to smooth consumption. Thus, all else equal, the reduction in savings would lead to a decline in the country's current account balance (Svensson and Razin, 1983). If the terms of trade deterioration is permanent, however, Obstfeld (1982) shows that there is a negative wealth effect that may increase domestic savings and thus increase the current account balance. Therefore, the net effect of a dollar appreciation shock can be ambiguous. ${ }^{2}$

Despite the ambiguity through the terms-of-trade effect, the expenditure-switching effect that reduces U.S. activity following a dollar appreciation shock implies a reduction in overall demand in the United States, including demand for foreign goods. This may in turn depress a foreign country's exports to the U.S., and thereby its overall economic activity. This possibility has been stressed by U.S. monetary policymakers in their assessment of the global implications of U.S. monetary policy during the global financial crisis and the subsequent recovery. For example, Ben Bernanke (Bernanke, 2014) recognized the possibility

\footnotetext{
${ }^{1}$ The presence of global monetary policy spillovers raises the question of the scope for international policy coordination. Most studies find that the effective scope for policy coordination is limited, although it has been argued that in exceptional circumstances, such as the global financial crisis, the potential gains from coordination can be large [e.g. Coeuré (2016)].

${ }^{2}$ This ambiguity can be resolved for a variety of special cases. For example, Kraay and Ventura (2000) demonstrate that in the case where investors allocate a marginal change in wealth in the same proportion as their existing asset holdings, a positive shock to income in a debtor country will increase its current account deficit. It has also been shown that the magnitude of the so-called expenditure-switching effect of an exchange rate change can be mitigated by firms pricing their goods to market [e.g. Devereux and Engel (2003)]. Alternatively, Agénor and Aizenman (2004) demonstrate that countries that face borrowing constraints may disproportionately save the proceeds of positive terms of trade shocks, improving their current account.
} 
that appropriate monetary policy for the United States may have undesirable consequences for its trading partners, particularly for emerging market economies that are vulnerable to abrupt changes in the pace of capital movements. But he stressed that any "costs" of these policies to those countries must be assessed against the benefits of supporting recovery in the advanced economies. Similarly, Federal Reserve Vice Chair Stanley Fischer noted that while the onset of policy tightening in the United States in 2015 may have put pressure on some emerging market assets, one reason for optimism was again that the policy tightening was taking place "... against the backdrop of a strengthening U.S. economy and in an environment of improved household and business confidence" (Fischer, 2014). The implications of both of these speeches is that the strength of U.S. demand is also of important concern for emerging market countries that rely on the U.S. as a market for their exports.

Furthermore, the sensitivity of a country's economic activity to a dollar appreciation shock may depend on the country's domestic policy regime and in particular, its exchange rate regime. The well-known "trilemma" argument implies that a flexible exchange rate regime allows a small open economy to have relatively independent monetary policy even though its capital account is open. Nonetheless, a dollar appreciation shock can still lead to real depreciation for a country if its monetary authority resists changes in domestic interest rates in response to the shock. For a country that tightly manages its exchange rate against the dollar, the impact of a dollar appreciation shock would be quite different. For such an economy, a dollar appreciation shock results in a real appreciation of its domestic currency relative to the rest of the world, which in turn reduces the competitiveness of the country's exports, exacerbating the adverse impact of the decline in U.S. demand resulting from the dollar appreciation.

One notable example of such a managed dollar exchange rate is China. China's currency (the renminbi, or RMB) closely followed the dollar over this period, as shown in Figure 1. As the dollar began appreciating in anticipation of policy normalization in the middle of 2014, the trade-weighted renminbi exchange rate also appreciated. By the end of our sample, the real effective exchange rate (REER) of the U.S. dollar had appreciated 2.77 percent, while that of the RMB had appreciated even more (3.21 percent). In contrast, both the tradeweighted South Korean won and the trade-weighted Japanese yen depreciated over the same period, although less than one might expect because the United States is the destination for only a modest share of these countries' exports relative to their trade with the rest of Asia and Europe. ${ }^{3}$

Empirical evidence suggests that in a country with a currency peg, domestic interest rates closely follow changes in the interest rates of the base country (Shambaugh, 2004). As a

\footnotetext{
${ }^{3}$ The Korean won REER depreciated by 0.40 percent, while the yen REER depreciated by 1.85 percent.
} 
result, increases in interest rates in industrial countries lead to contractions of economic activity in pegging countries, but have modest impacts on countries with a floating exchange rate regime (di Giovanni and Shambaugh, 2008). Broda (2004) also finds that countries with flexible exchange rate regimes are more insulated from terms of trade shocks. ${ }^{4}$ Similarly, Kim (2001) finds that expansionary U.S. monetary policy shocks from 1974 through 1996 tended to increase economic activity in the non-U.S. G6, primarily due to the implications of U.S. monetary shocks for global interest rates. ${ }^{5}$

In contrast to the exchange rate regime, there is less evidence that capital controls have a systematic impact on a nation's sensitivity to external monetary shocks [e.g. Miniane and Rogers (2007)]. The failure of capital controls to viably insulate a country from external monetary shocks has been associated with outstanding stocks of foreign currency debt (Towbin and Weber, 2000), which can result in national balance sheet deterioration in the wake of exchange rate depreciations, or changes in global risk tolerance [e.g. Rey (2015)].

In this paper, we evaluate the impact of dollar appreciation on economic conditions in the United States and its three major Asian trading partners: Korea, Japan, and China. For this purpose, we make a methodological extension of the empirical literature by using a factoraugmented vector autoregression (FAVAR) framework, similar to that used by Bernanke and Boivin (2003) and Bernanke et al. (2003) in the context of monetary policy shocks for the U.S. economy. To our knowledge, our paper is the first to use a FAVAR approach to evaluate the effects of exchange rate shocks in open economies. We estimate separate FAVAR representations for the United States, as well as each of the other Asian countries. In addition to using a FAVAR approach for the representation of a local activity index, we also estimate a latent index of foreign activity, individually weighted by trade volumes for each country, as described below. This country-specific "global conditions index" provides a novel way of conditioning for changes in relevant foreign activity and should assist in isolating the dollar appreciation effects in which we are interested.

As discussed by Bernanke and Boivin (2003), a FAVAR approach is particularly suited to the analysis of concepts that are imperfectly observed latent variables. As these authors note, a FAVAR approach may even be beneficial for evaluation of economic conditions in the

\footnotetext{
${ }^{4}$ In a recent paper, Schmitt-Grohé and Uribe (2013) find little impact of terms of trade shocks for a mixed group of poor and emerging market economies in a VAR framework. Kim and Yang (2012) examine the impact of U.S. monetary policy shocks on a number of East Asian countries, including Korea, Japan and China, using monthly data from June 1999 through June 2007. Their study characterizes China as pursuing a de facto crawling peg against the dollar, while the exchange rate regimes in Korea and Japan are more flexible.

${ }^{5}$ There is also evidence of spillovers from the unconventional U.S. policies pursued during the global financial crisis [e.g. Bowman et al. (2015) and Chen et al. (2016)].
} 
United States, as "economic activity" is a concept that is not directly observable. A number of alternative measures of these concepts may be useful, and the FAVAR approach provides one coherent approach for mixing these series through the use of factor analysis. Bernanke et al. (2003) argue that combining the data in this manner may provide superior estimates to using a single data series for each concept. Moreover, a FAVAR model has the advantage over a standard vector autoregressive (VAR) framework in mitigating the need for ad hoc specification decisions. As discussed in (Fernald et al., 2014), the use of a FAVAR framework suggests that these estimated latent activity factors are likely to be more accurate measures of activity than any individual reported data series. Moreover, they may also better reflect the information sets relevant to policymakers or used by economic agents to make decisions.

The FAVAR approach should be particularly useful for assessing economic activity in China. Skepticism about the accuracy of Chinese data is well-known [e.g. (Fernald et al., 2015)], both due to the extensive structural changes that have taken place recently in that country and also to systematic distortions aimed at reaching GDP growth targets. ${ }^{6}$

We include two activity factors: The first is a local conditions index (LCI), designed to reflect domestic economic activity. We load nine indicators of domestic economic activity, described in more detail below, and estimate the first principal component as a measure of domestic economic conditions. We also include a country-specific global conditions index (GCI) to control for the effects of changes in external conditions faced by each country. To estimate each country's individual GCI, we gather 11 monthly time series for the top 9 trading partners of each country. We then weight each of these by the trade share of each country, constructing a trade-weighted series for each measured indicator. We extract the first principal component of these 11 trade-weighted indicators along with 4 common series capturing global financial conditions to construct our GCI. We confirm that these activity indices are plausible, capturing well global cyclical fluctuations over the course of our sample.

We then include these activity factors in a six variable VAR model. We examine the responses of domestic economic activity to changes in the broad dollar index, using the GCI to control for other changes in global economic activity. Our U.S. VAR results confirm that an appreciation in the dollar results in reduced economic activity and inflation in the United States. For all three Asian countries, an appreciation in the broad dollar is also associated with a decline in both local activity and inflation. This result suggests that the adverse impacts on U.S. demand from dollar appreciation dominate the positive expenditureswitching terms of trade effects for these countries.

\footnotetext{
${ }^{6}$ Lescaroux and Mignon (2009) also construct a FAVAR model of the Chinese economy, concentrating on the implications for China of oil price shocks.
} 
This finding is robust to variations in both the measurement of local and external economic activity and VAR model specification. First, we consider variants of the local and global conditions indices. For the local conditions index, we add the trade balance as an argument to capture changes in external sector conditions. For the global conditions index, we remove world oil prices, which are likely to be strongly correlated with movements in the U.S. dollar and whose inclusion may lead to upwardly-biased estimates of the sensitivity of local conditions to dollar shocks. ${ }^{7}$ Second, we reorder our VAR specifications for China and Korea to place the U.S. dollar before the real exchange rate, which allows these countries' exchange rates to respond to dollar movements reflecting their exchange rate management vis-a-vis the dollar. The qualitative results we obtain in our base specification are robust to all of these alternative specifications. In particular, we retain the results that dollar appreciation results in a decline in both local activity and inflation in the Asian countries we study.

To assess the quantitative importance of the dollar appreciation from July 2014 through the end of our sample in December 2015, we conduct a counterfactual experiment based on historical decompositions in the estimated FAVAR model. In particular, we compare the actual path of the local activity indicator in each country to the counterfactual path when the broad dollar index is fixed at its value observed in June 2014. We find that the observed dollar appreciation has been a significant drag on U.S. economic activity. Absent the dollar appreciation, the U.S. LCI would have been one standard-deviation higher than the actual LCI observed during this period. Dollar appreciation has also substantially reduced local activity in South Korea, despite its floating exchange rate regime and relatively integrated capital market with the rest of the world. The effects of dollar appreciation on the LCIs of Japan and China are both small, but for different reasons. China tightly manages its exchange rate, but it also maintains a relatively closed capital account, limiting the opportunities for any arbitrage activity that could increase sensitivity to dollar shocks. Japan has a floating exchange rate regime, as in South Korea. However, Japan benefits from its safehaven currency status: an adverse global shock (such as a dollar appreciation) would lead to capital inflows to Japan from countries that are adversely affected by the shock, partially cushioning its impact on Japan's local economic activity.

The remainder of this paper is organized into 6 sections. Section 2 discusses our empirical methodology and our construction of the local and global activity indices for the four countries in our study. Section 3 discusses our results. Section 4 considers the robustness of our base results to a variety of sensitivity analyses. Section 5 conducts counterfactual exercises for the case where the dollar did not appreciate since the middle of 2014. Lastly, section 6 concludes.

\footnotetext{
${ }^{7}$ We thank a referee for recommending this sensitivity test.
} 


\section{EMPIRICAL METHODS}

We estimate the macro effects of dollar appreciation on economic activity using a FAVAR approach in the spirit of Bernanke and Boivin (2003) and Bernanke et al. (2003). Observed individual time series such as industrial production and the unemployment rate are in general imperfect measures of economic activity. This concern is particularly relevant for a country like China, where data availability is limited and official data are not completely reliable [e.g. Fernald et al. (2014)]. The FAVAR framework has the additional advantage relative to a simple VAR in that activity is summarized by a small number of factors, so that the parameters to be estimated in our VAR representation are limited to a small number, which helps improve the accuracy of our estimates.

For each country, we generate two indices, a local conditions index (LCI) and a global conditions index (GCI). These indices are generated by combining information from a wide range of observable data series. The local conditions index is generated from local observable economic indicators, while the global conditions index is generated from indicators collected from each country's major trading partners, weighted by trade volume. We then put these activity indicators along with several observable variables into a VAR and estimate that VAR model using the Bayesian approach of Sims and Zha (1998).

II.1. Data and activity indicators. To construct the LCI for each country, we extract the first principal component of a number of domestic economic indicators in that country. Denote by $X_{t}$ those observable indicators and by $F_{t}$ the underlying factors. The observables are related to the factors through

$$
X_{t}=\Lambda F_{t}+u_{t}
$$

where $u_{t}$ denotes idiosyncratic noises and $\Lambda$ is the matrix of factor loading parameters. For each country, the observable data $X_{t}$ is a vector of nine domestic variables, including industrial production, unemployment, housing starts or permits, stock prices, 1-year government bond yields, 2-year government bond yields, M1, M2, and the producer price index (see the Appendix for a description of the data). ${ }^{8}$

To construct the GCI for each country, we gather data for 11 time series for the top nine trading partners of that country. Indicator variables included are industrial production, unemployment, the consumer price index, housing starts or permits, equity prices, 1-year government bond yields, 2-year government bond yields, 3-month government bond yields,

\footnotetext{
${ }^{8}$ Some of the variables included in the construction of the GCI, such as the consumer price index, are not included in the LCI because they are introduced as separate arguments in our final VAR specification.
} 
M1, M2, and the producer price index. ${ }^{9}$ We then compute the principal components of tradeweighted averages of those 11 time series plus four common series that include oil prices, emerging market bond yield index (EMBI), the economic sentiment indicator of the euro zone, and the economic sentiment indicator of the European Union. The GCI is measured as the first principal component. ${ }^{10}$

Figure 2 displays the LCI and GCI for each of the four countries for the appropriate sample periods. The grey areas represent U.S. recession periods. All of the countries' LCIs and GCIs appear to be plausible, and in particular all reflect the impact of the global financial crisis and the different experiences of these countries during that crisis and afterwards.

The US LCI is highly correlated with its GCI, reflecting the dominant role of the US in the global economy, and particularly pronounced influence the US economy has among its primary trading partners. Both the LCI and GCI are pro-cyclical: they rise in booms and fall in recessions. However, in the more recent periods from 2013 through the end of 2015, the US LCI recovered more rapidly than the GCI, reflecting the relatively slow recovery of the major trading partners of the US, in particular the sluggish recoveries of the euro area and Japan.

Korea's LCI and GCI are also highly correlated, both rising in booms and falling in recessions. However, the Korean LCI seems to be far less volatile than its GCI, particularly during the boom years preceding the global financial crisis, as Korean growth rates fell short of those of their major trading partners, including the U.S., during this period. The Korean LCI also declined less precipitously than its GCI during the global financial crisis, and experienced a quicker recovery in its LCI, suggesting that Korea was relatively more successful than its primary trading partners at stabilizing the impact of that event. Of course, others have found that growth experiences prior to the crisis were negatively correlated with growth experiences during the crisis [e.g. Rose and Spiegel (2012)], which is consistent with this result for Korea. In addition, we see that Korea's LCI also recovered more rapidly than its GCI from the global financial crisis.

Japan's LCI and GCI are also closely correlated. The drop in the Japanese GCI is notably steep during the Great Recession, while the falloff in the Japanese activity indicator during that period is surprisingly tranquil relative to the steep drops in trade and GDP experienced by Japan during that episode. Both Japan's LCI and GCI appear to pick up at the end of

\footnotetext{
${ }^{9}$ The Appendix describes the time series data used and provides a list of the largest trading partners for each country.

${ }^{10}$ The first principal component of the LCI accounts for $49 \%$ of the variance of the LCI for the US, $34 \%$ for Korea and Japan, and 39\% for China. The first principal component of the GCI accounts for about $40 \%$ of the variance of the GCI for each country. The explanatory powers of the 2 nd principal components are substantially smaller, approximately $21 \%$ for the US, $20 \%$ for Japan, $19 \%$ for Korea and $20 \%$ for China.
} 
MEASURING THE EFFECTS OF DOLLAR APPRECIATION ON ASIA:

2012, presumably in response to optimism surrounding the election of Shinzo Abe as Prime Minister and the launching of his "Abenomics" economic reforms. However, the pickup in Japan's LCI in particular is almost completely reversed by the end of our sample.

Finally, China's LCI does not seem to co-move closely with its GCI. In particular, the LCI and GCI diverged after 2009. This divergence likely reflects the effects of China's large-scale fiscal stimulus, which accelerated that country's economic recovery subsequent to the global financial crisis. It can be seen that China's recovery commenced prior to those in the US and Japan, as reflected in the earlier trough to China's LCI series relative to its GCI series. However, since 2010, China's LCI has declined steadily, consistent with the country's growth slowdown.

\section{The FAVAR MOdEL AND The ESTIMATION RESUlts}

In this section, we discuss the estimated impulse responses to a dollar exchange rate shock in our FAVAR specifications for each of the four countries in our sample.

III.0.1. The US. We begin with the US FAVAR model. The US model includes the local conditions index, the inflation rate (measured by year-over-year changes in the consumer price index), the short-term nominal interest rate (the three-month Treasury bills rate), the global conditions index, and the broad trade-weighted US dollar index, in that order. This ordering of the variables reflects our Cholesky identification restriction that the latent factors (LCI and GCI) and the observables (inflation and the interest rate) do not respond to a dollar exchange rate shock in the impact period, while the dollar index is allowed to respond to the other shocks in the VAR. We estimate the impulse responses using Bayesian methods with Sims and Zha (1998) priors. $^{11}$

Figure 3 shows the estimated impulse responses in the US FAVAR model to one standard deviation shock in the broad US dollar. The solid lines represent the median impulse responses and the dashed lines show the range of the $68 \%$ confidence bands.

Our estimation shows that a nominal appreciation of the dollar leads to an initial decline in both local activity and inflation. The decline in local activity suggests the dominance of the expenditure-switching effect of the dollar appreciation. The dollar appreciation reduces the relative price of imported foreign goods. Thus, net demand for foreign goods rises and demand for US goods falls. This reduction in aggregate demand for US goods leads

\footnotetext{
${ }^{11}$ An advantage of using the Bayesian priors proposed by Sims and Zha (1998) is that it helps improve the accuracy of the estimates when the time series dimension of the sample is relatively short, as they are in our samples in this paper.
} 
to declines in US local activity and inflation. Furthermore, the declines in import prices directly contribute to declines in overall inflation. ${ }^{12}$

The dollar appreciation shock modestly pushes down the nominal interest rate, although our point estimate of this effect is close to zero. Note that the dollar does not return to its initial value over the course of our simulation, but instead continues to appreciate modestly. The expected appreciation in the exchange rate pushes down the local nominal interest rate over this period. In addition, the decline in aggregate demand also motivates monetary easing in the form of reduced local interest rates. However, this response is muted during the latter period of our sample because of the zero bound limitation on monetary policy easing through conventional channels.

The dollar appreciation also leads to a notable decline in the GCI, suggesting that the contraction in the US also leads to a contraction in the economic activity of its trading partners. This result suggests that declines in U.S. activity following the dollar appreciation shock can adversely affect its trading partners, despite the expenditure switching effect.

III.0.2. Korea. We next turn to the case of Korea. Figure 4 shows the impulse responses and the $68 \%$ confidence bands in the estimated Korean FAVAR model. This is a six-variable model that includes Korea's LCI, CPI inflation rate, short-term nominal interest rate, GCI, the real effective exchange rate (REER), and the nominal broad dollar index. A main difference with the US FAVAR is the inclusion of Korea's REER, which captures potential effects of changes in Korea's terms of trade relative to its trading partners other than the US.

As shown in Figure 4, a dollar appreciation shock reduces the GCI for Korea, reflecting weakened demand from the US. The shock also leads to a real depreciation of Korea's currency, as expected. Given this depreciation in the real value of the Korean won, the expenditure-switching effect would act towards raising Korean export demand and increasing its aggregate activity.

However, our impulse responses show that Korea's LCI and inflation both fall in response to the dollar appreciation shock, suggesting that declines in demand for Korean exports dominate the stimulus provided by real depreciation in Korea. This is somewhat surprising, since Korea's trade share with the U.S. is the lowest among the three Asian countries that we

\footnotetext{
${ }^{12}$ The finding that U.S. activity and inflation decline on impact of the dollar appreciation shock appears to be different from that obtained by Kim (2001), who reports that an expansionary monetary policy shock has real effects with a lag. This difference reflects the fact that we take the dollar shock as exogenous, so that the dollar appreciates instantaneously following the shock. However, Kim (2001) considers a monetary policy shock, which is likely to have delayed effects on the real exchange rate.
} 
consider. ${ }^{13}$ It is therefore likely that the Korean LCI responses may also reflect the adverse impact of dollar appreciation on its other trading parteners, such as China and Japan.

Furthermore, the real depreciation corresponds to a deteriorated terms of trade for Korea and thus reduces income. To the extent that terms-of-trade deterioration is transitory, households choose to smooth consumption by reducing their savings or by borrowing from abroad, as predicted by the Harberger-Laursen-Metzler effect. This would act towards reducing the current account balance and adding to the recessionary effects from weakened global demand following the dollar appreciation shock.

Overall, the Korean impulse responses appear to well-represent a relatively small open economy that is dependent on the U.S. as an export market and engages in some degree of exchange rate management. While the appreciation in the dollar may enhance the relative competitivenss of the country's exports to the U.S. and its other trading partners, which would ceteris paribus tend to stimulate Korean activity, our finding suggests that the boost from this expenditure-switching effects for Korean local activity is outweighted by the adverse impact of declines in global demand following the dollar appreciation shock.

III.0.3. Japan. We next consider Japan. Figure 5 shows the impulse responses and the $68 \%$ confidence bands in the Japanese FAVAR model. The VAR model specification is identical to that for Korea. The patterns of impulse responses are also similar to those in Korea. There is a decline in Japan's GCI, reflecting reduced activity among Japan's primary trading partners. This reduced activity seems to drag on domestic conditions, as we observe declines in both Japanese local activity and inflation. Note that these declines persist and bottom out with a lag, as we would expect.

The decline in domestic demand calls for domestic monetary poicy easing, as reflected by the decline in Japanese short-term nominal interest rates. However, in much of our sample period, the Japanese policy rates were constrained by the zero lower bound (ZLB), which went slightly negative only very recently. The ZLB reduces the capacity of monetary policy accommodation for weakened domestic conditions. Thus, the observed declines in the Japanese short-term interest rate following the dollar appreciation shocks are likely driven by its responses before the ZLB became binding.

In contrast to the case of Korea, however, the Japanese REER appreciates following the dollar appreciation shock. This is surprising, as the yen is commonly considered a freelyfloating currency which would be expected to depreciate in response to a positive shock to the dollar. The real appreciation of the yen therefore likely reflects that currency's safehaven status during and around the global financial crisis period. As shown in Figure 1, in

\footnotetext{
${ }^{13}$ The average U.S. trade share for Korea is around $15.4 \%$, while for Japan and China, it is $20 \%$ and $22.6 \%$ respectively.
} 
the crisis period of 2008-2009, both the dollar and the yen appreciated substantially. Our inclusion of this period may exaggerate the degree of positive correlation between the yen and the dollar.

III.0.4. China. Finally, we turn to the case of China. Our VAR specification for China is again identical to those for Korea and Japan. Figure 6 shows the impulse responses to a one standard deviation shock to the broad dollar index and the $68 \%$ confidence bands estimated from the Chinese FAVAR model.

Our qualitative results for China differ from those for Korea and Japan for a number of reasons: First, China has tightly managed its bilateral exchange rate with the dollar over much of our sample period. While there was some exchange rate smoothing in Korea over the course of our sample, it was much more freely floating than the renminbi over this period. In addition, China is a large importer of commodities, whose real costs in dollars tend to decline with dollar appreciation. To the extent that the renminbi follows the dollar, dollar appreciation reduces the real costs of China's commodity inputs.

China's exchange rate regime was changed following the global financial crisis, as the RMB was allowed to appreciate modestly but persistently (see Figure 1). This response reflected the policy responses of the People's Bank of China to unconventional monetary policy in the United States and other advanced economies that lowered yields on foreign interest rates. The decline in foreign interest rates raised the cost of sterilization to the PBOC under China's capital controls. To avoid a run up of domestic inflation from reduced sterilization activity, the PBOC allowed the RMB to appreciate. The PBOC also raised reserve requirements many times. As discussed in Chang et al. (2015), despite these policy interventions, the PBOC still faced a tradeoff between sterilization costs and inflation stability under capital controls, and inflation surged from $-1.5 \%$ in 2009 to $6.5 \%$ in 2012 .

This experience demonstrates that despite China's formally-closed capital account, there are leakages and it still feels the impact of foreign exchange rate shocks. As such, we obtain interesting dynamics in our estimated Chinese impulse responses to dollar appreciation shocks for China in Figure 6. In particular, a dollar appreciation shock reduces China's global conditions index. This likely reflects not only the decline in U.S. demand, but also the declining activity in Japan and Korea that we observed above, as both of these countries are important trading partners for China.

The decline in external demand (reflected by the decline in China's GCI) results in declines in both Chinese economic activity and inflation. This result is intuitive as direct competition between the U.S. and China is modest compared to the importance of the US as a market for Chinese final goods, so expenditure-switching effects from dollar appreciation would be expected to be modest. 
Despite its exchange rate management, China's real effective exchange rate also falls slightly. These real exchange rate movements are likely attributable to movements in inflation. The drop in inflation combined with a relatively fixed dollar peg can explain the modest observed decline in China's REER as observed in the impulse responses.

The observed reduction in inflation reflects the opposite case from that discussed in Chang et al. (2015). In that exercise, a negative interest rate shock in the U.S. raised the Chinese cost of sterilization and induced the Chinese government to sterilize less and monetize more, resulting in an increase in realized inflation. In our current analysis, a dollar appreciation - holding all else equal - reduces the costs of sterilization, and the PBOC would rationally respond by sterilizing more, reducing inflationary pressure. This is an additional channel attributable to China's unique capital account situation. Of course, as in the cases of Korea and Japan, Chinese inflation is also directly reduced by the declines in Chinese demand and in the relative price of commodities following the dollar appreciation.

The reduction in China's interest rate reflects monetary policy easing in response to the recessionary effects of the shock. Note that Chinese monetary policy independence is sustained despite its pegged exchange rate due to its capital control policies.

\section{Robustness CHECKS}

In this section, we examine the robustness of our empirical findings by considering alternative measurements of the LCI and GCI and alternative FAVAR specifications. In particular, we first perturb the measurement of each country's LCI by including its trade balance (as a share of GDP) as an additional observable indicator. The inclusion of trade balances in the LCI reflects potential links between movements in the dollar and a country's trade balance, the effects of which we would like to control when we estimate the impulse responses following the dollar appreciation shock. We then consider an alternative measure of the GCI by removing oil prices from the set of observable indicators to avoid the possibility of exaggerating the correlation between the GCI and the dollar shock caused by correlations between oil price movements and changes in the dollar value. Finally, we consider an alternative FAVAR

specification for Korea and China by reordering each country's real exchange rate as the last variable, so that the model allows the real exchange rates in these countries to respond to the dollar shock in the impact period, reflecting their active exchange-rate management vis-a-vis the dollar.

IV.1. An alternative LCI specification. We first perturb the LCI specification by adding the trade balance as an indicator variable for all four countries. We then reestimate the FAVAR specifications for the four countries in our study. The impulse responses are shown 
in Figure 7 where, to conserve space, we only show the responses of the LCI and domestic inflation in each country. ${ }^{14}$

Figure 7 shows that the qualitative results are quite similar to those in our base specification. All of the countries exhibit a persistent decline in both economic activity and inflation in the wake of an appreciation of the dollar. For the United States, this is to be expected and and is consistent with an expenditure-switching effect. For the Asian countries in our study - as in our base specification - the decline in activity and inflation reflect reduced external demand from the U.S. and other trading partners, which dominates the boost from the expenditure-switching effect as the domestic currency depreciates against the dollar.

IV.2. An alternative GCI specification. We next remove oil from the GCI. Oil prices are highly negatively correlated with movements in the dollar, so their inclusion as an activity indicator in our GCI may exaggerate the correlation between foreign conditions and dollar movements. Figure 8 displays the impulse responses to a dollar appreciation shock for each of the four countries in our sample. Again, to conserve space, we focus on the responses of the LCI and domestic inflation for each country.

Figure 8 shows that the qualitative results in our base specification are robust to this alternative measure of the GCI. Similar to the impulse responses that we obtained from the base specification, all of the countries exhibit lagged declines in both local activity and inflation. As in our base specification, the impact on activity in China is weakest among the Asian nations we consider, despite the close movements of the renminbi and the dollar over this sample period. Overall, however, the impacts are negative for all of the Asian countries, supporting our conclusion for the base specification that the expenditure-switching effect of dollar appreciation is dominated by impact of decreased US demand.

IV.3. An alternative ordering in the FAVAR model. We now consider an alternative ordering of the FAVAR models for Korea and China. In particular, we order their real exchange rate as the last variable, so that the real exchange rates can respond to the dollar appreciation shock in the impact period. This re-ordering of the FAVAR model reflects the possibility that those countries actively manage their exchange rate policies following movements in the dollar. This is particularly true for China, where the government has maintained relatively tight control over movements in the renminbi relative to the dollar over our sample period. While the Korean won was unambiguously more flexible, it was also managed to some extent by Korean authorities. As a result, while real exchange rate movements likely reflect movements in local prices to some extent, as we discussed in our

\footnotetext{
${ }^{14}$ The full VAR results are available from the authors upon request.
} 
review of our base specification results, they may also reflect movements in the local nominal exchange rate.

Figures 9 and 10 show the estimated impulse responses for Korea and China, respectively, under this alternative FAVAR ordering. The Korean impulse response functions are almost identical to those in the base specification. In particular, despite our reordering, we observe very similar responses to the dollar shock for the won. As a result, the dynamics for the other variables in our model, in particular those for Korean economic activity and inflation, are almost identical to those in our base specification.

In contrast to our Korean results, the impulse responses for China under this alternative ordering of the FAVAR model seem to be quite different. In particular, rather than the real depreciation in the renminbi that we observed in our base specification, we now observe a large positive and persistent movement in the renminbi. This pattern appears to be more realistic because the movements in the renminbi and the US dollar are highly correlated over our sample period.

Among the other variables, the qualitative results are quite similar to those we obtained in our base specification. One modest exception is that we do observe a deeper decline in our point estimate for Chinese local economic activity as proxied by the LCI. Still, the magnitudes of these predicted declines for China remain more modest than those we found for the other Asian nation in our sample. This more modest decline in activity remains surprising in light of the close movements of the renminbi and the dollar over this period, which would indicate that China's resulting real exchange rate appreciation in the wake of the positive dollar shock would result in even further recessionary effects on Chinese output and inflation.

Overall, while the reordering appears to generate more plausible movements in the real exchange rate for China, the qualitative conclusions from our baseline specification continue to hold: the demand effect from US dollar depreciation dominates the expenditure-switching effect, resulting in declines in local activity and inflation for both Korea and China.

\section{Counterfactual exercise}

To assess the quantitative importance of the dollar appreciation from July 2014 through the end of our sample in December 2015, we conduct a counterfactual experiment by fixing the value of the broad dollar index during this period to its actual value in June 2014. In other words, we turn off the shock to the dollar index between July 2014 and December 2015, but keep all the other shocks and parameters at their estimated values in the FAVAR. We then simulate the time series of the variables in the FAVAR for this treatment period. 
The difference between the simulated counterfactual path of a variable and its actual path in the data captures the contribution of the dollar shock during the treatment period.

Figure 11 displays the actual time series of the LCI for each of the four countries from July 2014 to December 2015 (the solid lines) and the counterfactual simulated path of the LCI when the dollar shock is turned off (the dashed lines). We normalize the LCIs (both actual and counterfactual) so that the value in July 2014 for each country is set to 0.

Figure 11 shows that the dollar appreciation since mid-2014 has substantially depressed US local activity. In particular, absent the dollar shock, the US local activity index would have been about one standard deviation higher than its observed value. Thus, we find that dollar appreciation has been a significant drag on the US economy. We also find that the dollar appreciation has affected all of our three Asian economies, although to different extents. In particular, it has substantially reduced local activity in Korea. Absent the dollar shocks, Korea's local activity index by the end of our sample would have been close to that in mid-2014. But the actual LCI for Korea is substantially lower (about 0.7 standard deviation lower at the end of our sample than in mid-2014). The effects of dollar appreciation on Japan's and China's LCIs are much smaller.

Similarly, Figure 12 displays the actual time series of inflation (solid lines) along with the counterfactual series (dashed lines) from July 2014 to December 2015. For the US, the dollar appreciation has contributed significantly to the low CPI inflation in this period. In the counterfactual without dollar shocks, the US inflation rate would have been on average about one percentage point higher than the actual inflation rate.

The dollar appreciation since July 2014 has also contributed to low inflation in Korea. Absent dollar shocks in this period, Korea's CPI inflation would have been half a percentage point higher than the actual value. The effects of dollar shocks on Japan's and China's inflation are again relatively small.

It is unsurprising that Korea stands out among our three Asian economies as the most exposed to a positive dollar shock. China manages its exchange rate closely, but it also closely restricts capital movements, limiting the opportunities for any arbitrage activity that could increase sensitivity to dollar movements. Japan has floating regime, as in South Korea. However, Japan benefits from its safe-haven currency status, so that an adverse global shock (such as a dollar appreciation) leads to capital inflows to Japan from other countries that are negatively affected by dollar appreciation, partially cushioning the decline in Japan's local economic activity. 


\section{Conclusion}

We evaluate the implications of a dollar appreciation shock on U.S. economic conditions and also on three major Asian economies: Korea, Japan, and China. We use a FAVAR framework to estimate country specific local and global condition indices as latent variables. To our knowledge, our paper is the first to apply the FAVAR methodology to the question of the implications of exchange rate shocks.

Our results demonstrate that dollar appreciation results in decreased economic activity for all of countries in our study. The decline in U.S. activity is a direct effect of reduced competitiveness through the standard expenditure-switching channel. For the Asian trading partners in our study, in contrast, our results demonstrate that the expansionary expenditure-switching effects of dollar appreciation are more than offset by, among other things, the reduction in demand of the U.S. and other Asian trading partners. Our base result is robust to a number of perturbations in the specifications of our conditions indices, including adding the trade balance to our local conditions index estimates, removing oil prices from our global conditions index specifications, and reordering our VAR specifications for Korea and China to allow their real exchange rate movements to respond to US dollar shocks.

Finally, we use our estimated FAVAR model to evaluate the implications of the recent dollar appreciation since mid-2014. We run counterfactuals, asking what activity and inflation would have been, were there no dollar appreciation since July 2014. Our findings suggest that all of the countries in our study would have experienced greater activity in the absence of the appreciation, but that the Korean economy was particularly exposed. Our point estimates suggest that the Korean economy's local conditions index would have been about 0.7 standard deviations higher than it was at the end of our sample in the absence of the dollar appreciation shock. The quantitative effects of the dollar appreciation on local activity for both Japan and China since July 2014 are relatively muted.

Overall, Asian economic conditions appear to be closely tied to U.S. monetary policy, despite the apparent differences in economic structures and policy regimes. Moreover, they favor the contention made by monetary policymakers during the crisis, such as Federal Reserve Chair Ben Bernanke, that the paramount interest of emerging market economies during the crisis was the recovery of the advanced economies. Expenditure-switching consequences of dollar movements, at least, appear to have been second-order over the course of our sample. 


\section{Appendix A. Data Descriptions}

A.1. Local conditions index. We construct local conditions indices (LCI) for the United States, South Korea, Japan and China based on a number of monthly time series data. In particular, each country's LCI is the first principal component of the following series:

(1) Industrial production (log growth)

(2) Unemployment rate

(3) Housing starts/permits (log unit)

(4) Stock price index (log growth)

(5) One-year government bond yields

(6) Two-year government bond yields

(7) M1 (log growth)

(8) M2 (log growth)

(9) Producer price index (log growth).

For China, the samples for the two-year and one-year government bond yields are very short. We replace them by China's interbank loan rates.

A.2. Global conditions index. We construct global conditions indices (GCI) for each country based on trade-weighted averages of 11 time series variables in that country's major trading partners along with four common series.

The 11 country-specific variables include

(1) Industrial production (log growth)

(2) Unemployment rate

(3) Consumer price index (log growth)

(4) Housing starts/permits $(\log )$

(5) Stock price index (log growth)

(6) One-year government bond yields

(7) Two-year government bond yields

(8) Three-month government bond yields

(9) M1 (log growth)

(10) M2 (log growth)

(11) Producer price index (log growth)

The four common series include

(1) Brent crude oil price $(\log )$

(2) Emerging market bond yield index, EMBI

(3) European Commission Economic SentiMent Indicator Eurozone

(4) European Commission Economic SentiMent Indicator EU 
TABLE A1. Major trading partners

\begin{tabular}{ccccc}
\hline \hline Trade rank & United States & China & Korea & Japan \\
\hline 1 & Canada & United States & China & China \\
2 & China & Euro area & United States & United States \\
3 & Euro area & Japan & Japan & Euro area \\
4 & Mexico & Korea & Euro area & Korea \\
5 & Japan & Taiwan & Singapore & Australia \\
6 & Korea & Australia & Taiwan & Australia \\
7 & United Kingdom & Singapore & Australia & Thailand \\
8 & Brazil & Malaysia & Vietnam & Malaysia \\
9 & Taiwan & Russia & Russia & Indonesia \\
\hline
\end{tabular}

TABLE A2. VAR sample dates

\begin{tabular}{ccc}
\hline \hline Country & Start & End \\
\hline United States & $1997 \mathrm{~m} 12$ & $2015 \mathrm{~m} 12$ \\
Korea & $1999 \mathrm{~m} 10$ & $2015 \mathrm{~m} 12$ \\
Japan & $1997 \mathrm{~m} 12$ & $2015 \mathrm{~m} 11$ \\
China & $2002 \mathrm{~m} 1$ & $2015 \mathrm{~m} 5$ \\
\hline
\end{tabular}

To construct the GCI for a country, we compute the first principal component of the 11 trade-weighted series plus the four common series. We focus on the 9 largest trading partners determined by total trade (imports plus exports) in 2014, so that the composition of the trading partners remain constant over time. All trade data are taken from the IMF Direction of Trade Statistics database. Table A1 shows the top 9 major trading partners of each country in our sample.

A.3. VAR samples. We run the VARs on the sample allowed by data availability through 2015. Table A2 shows the dates for each VAR. 


\section{REFERENCES}

Agénor, P.-R. And J. Aizenman (2004): "Savings and the Terms of Trade Under Borrowing Constraints," Journal of International Economics, 63, 321-340.

Bernanke, B. S. (2014): "The Federal Reserve and the Global Economy," Per Jacobsson Foundation Lecture 2014 Annual Meetings of the International Monetary Fund and the World Bank Group.

Bernanke, B. S. And J. Boivin (2003): "Monetary Policy in a Data Rich Environment," Journal of Monetary Economics, 50, 525-546.

Bernanke, B. S., J. Boivin, And P. Eliasz (2003): "Measuring the Effects of Monetary Policy: A Factor-Augmented Vector Autoregressive (FAVAR) Approach," Quaterly Journal of Economics, 50, 387-422.

Bowman, D., J. M. Londono, And H. SApriza (2015): "U.S. Unconventional Monnetary Policy and Transmission to Emerging Market Economies," Journal of International Money and Finance, 55, 27-59.

Broda, C. (2004): "Terms of Trade and Exchange Rate Regimes in Developing Countries," Journal of International Economics, 63, 31-58.

Calderon, C. A., A. Chong, And N. V. Loayza (2002): "Determinants of Current Account Deficits in Developing Coutnries," B.E. Journal of Macroeconomics, 2, 1-31.

Chang, C., Z. Liu, and M. M. Spiegel (2015): "Capital Controls and Optimal Chinese Monetary Policy," Journal of Monetary Economics, 74, 1-15.

Chen, Q., A. Filardo, D. He, and F. Zhu (2016): "U.S. Unconventional Monnetary Policy and Transmission to Emerging Market Economies," Journal of International Money and Finance, forthcoming.

Coeuré, B. (2016): "The Internationalisation of Monetary Policy," Journal of International Money and Finance, forthcoming.

Devereux, M. B. And C. Engel (2003): "Monetary Policy in the Open Economy Revisited: Price Setting and Exchange Rate Flexibility," Review of Economic Studies, 70, 765-783.

di Giovanni, J. And J. C. Shambaugh (2008): "The Impact of Foreign Interest Rates on the Economy: The Role of the Exchange Rate Regime," Journal of International Economics, 74, 341-361.

Fernald, J. G., E. Hsu, And M. M. Spiegel (2015): "Is China Fudging Its Figures?: Evidence from Trading Partner Data," Federal Reserve Bank of San Francisco.

Fernald, J. G., M. M. Spiegel, And E. T. Swanson (2014): "Monetary Policy Effectiveness in China: Evidence from a FAVAR Model," Journal of International Money and Finance, 49, 83-103. 
MEASURING THE EFFECTS OF DOLLAR APPRECIATION ON ASIA:

A FAVAR APPROACH 21

Fischer, S. (2014): "Challenges of the Global Financial System: Risks and Governance under Evolving Globalization," Speech at Bank of Japan-International Monetary Fund High-Level Seminar.

KIm, S. (2001): "International Transmission of U.S. Monetary Policy Shocks: Evidence from VAR's," Journal of Monetary Economics, 48, 339-372.

KIM, S. AND D. Y. YANG (2012): "International Monetary Transmission in East Asia: Floaters, Non-Floaters, and Capital Controls," Japan and the World Economy, 24, 305316.

KraAy, A. And J. Ventura (2000): "Current Accounts in Debtor and Creditor Countries," Quarterly Journal of Economics, 115, 1137-1136.

Lescaroux, F. And V. Mignon (2009): "Measuring the Effects of Oil Prices on China's Economy: A Factor-Augmented Atuoregressive Approach," Pacific Economic Review, 14, $410-425$.

MendozA, E. (1995): "The Terms of Trade, the Real Exchange Rate, and Economic Fluctuations," International Economic Review, 36, 101-137.

Miniane, J. And J. H. Rogers (2007): "Capital Controls and the International Transmission of U.S. Money Shocks," Journal of Money, Credit and Banking, 39, 1003-1035.

Obstfeld, M. (1982): "Aggregate Spending and the Terms of Trade: Is There a LaursenMetzler Effect?" QJ.E. 97 (May 1982): 251-70." Quarterly Journal of Economics, 97, 251-270.

Rey, H. (2015): "Dilemma, Not Trilemma: The Global Financial Cycle and Monetary Policy Independence," NBER Working Paper no. 21162.

Rose, A. K. And M. M. Spiegel (2012): "Cross-Country Causes and Consequences of the 2008 Crisis: Early Warning," Japan and the World Economy, 24, 1-16.

SchmitT-Grohé, S. And M. Uribe (2013): "How Important Are Terms of Trade Shocks?" Mimeo.

Shambaugh, J. C. (2004): "The Effeect of Fixed Exchange Rates on Monetary Policy," Quarterly Journal of Economics, 119, 301-352.

Sims, C. A. And T. Zha (1998): "Bayesian Methods for Dynamic Multivariate Models," Internatinal Economic Review, 39, 949-968.

Svensson, L. E. O. And A. Razin (1983): "The Terms of Trade and the Current Account: The Harberger-Laursen-Metzler Effect," Journal of Political Economy, 91, 97-125.

Towbin, P. And S. WeBer (2000): "Limits of Floating Exchange Rates: The Role of Foreign Currency Debt and Import Structure," Journal of Development Economics, 45, 179-194. 


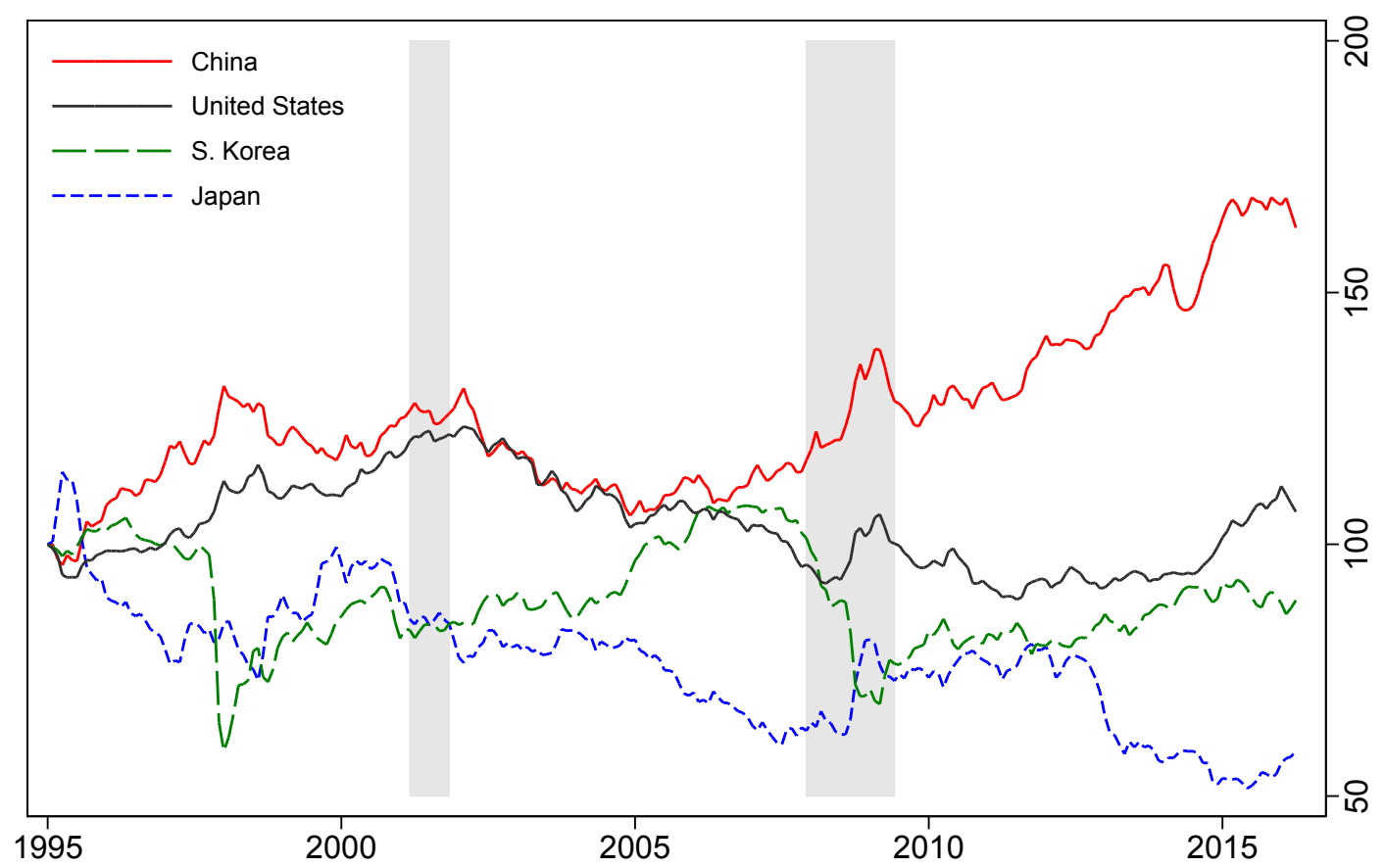

FigurE 1. Real effective exchange rates, indexed to 100 in January 1995. 

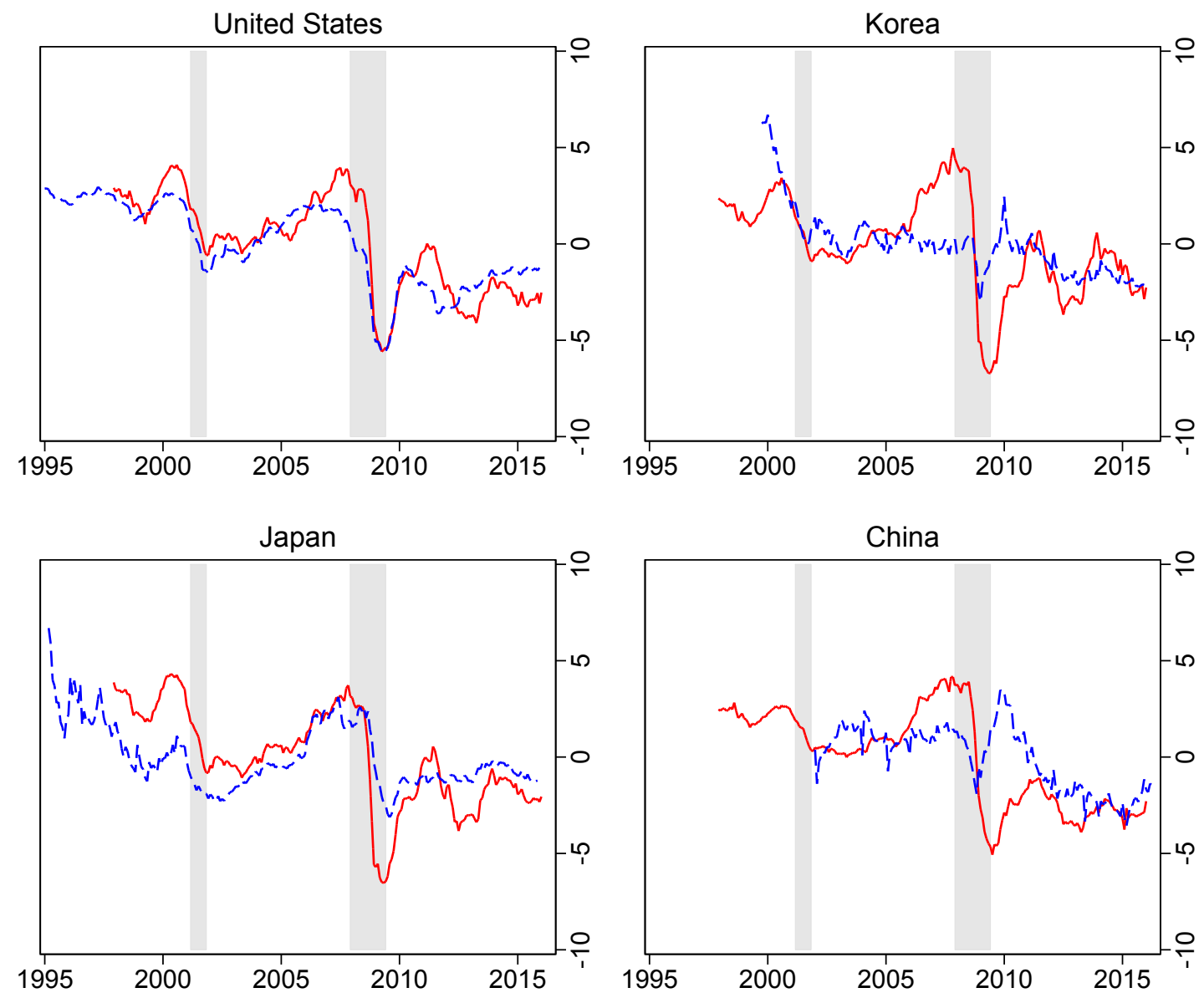

Global conditions

Local conditions

Figure 2. Global conditions index and local conditions index for the four countries in our sample. 

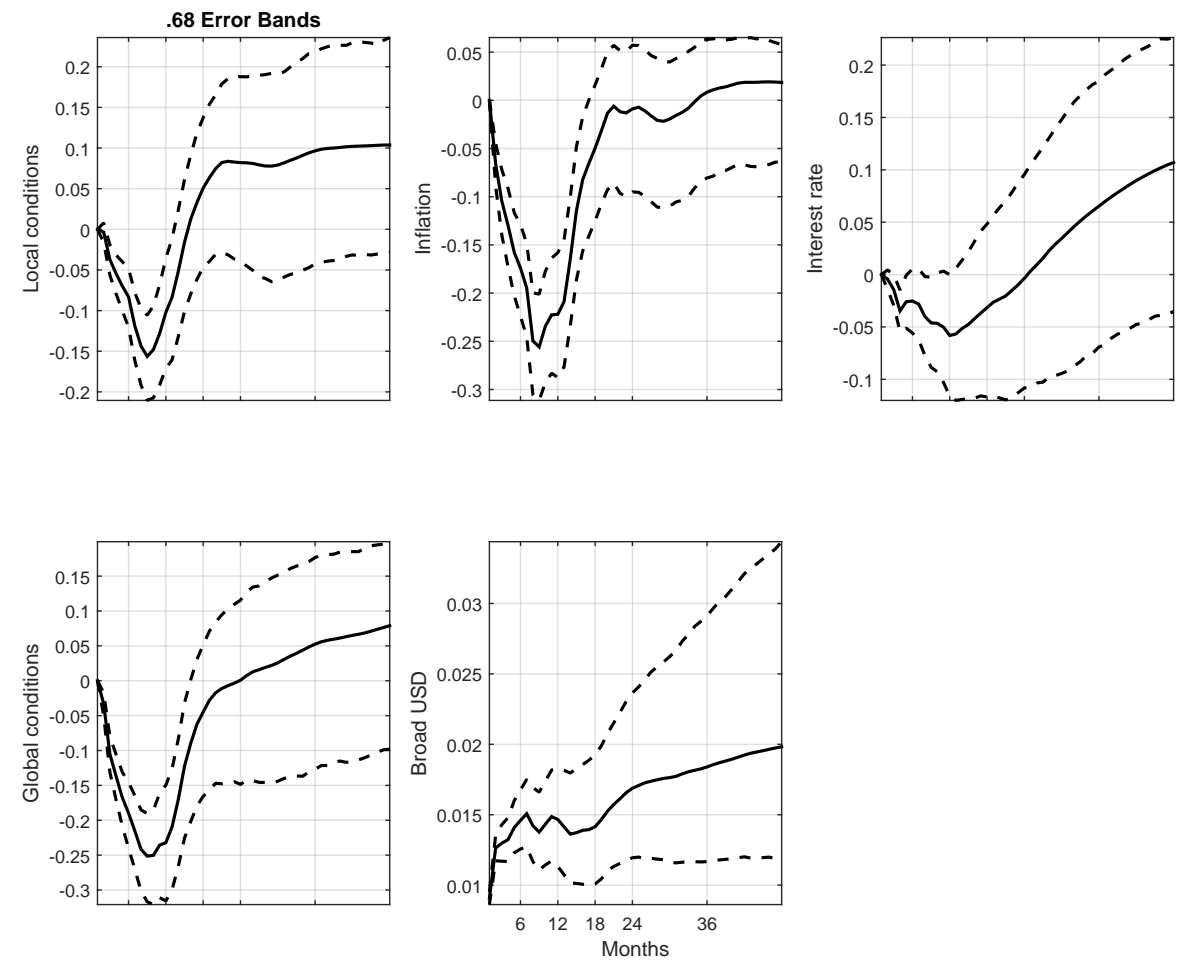

FiguRE 3. Impulse responses to a positive one standard deviation shock to the broad dollar index in the benchmark FAVAR model for the US. The solid lines represent the median impulse responses. The dashed lines indicate the $68 \%$ confidence bands. 

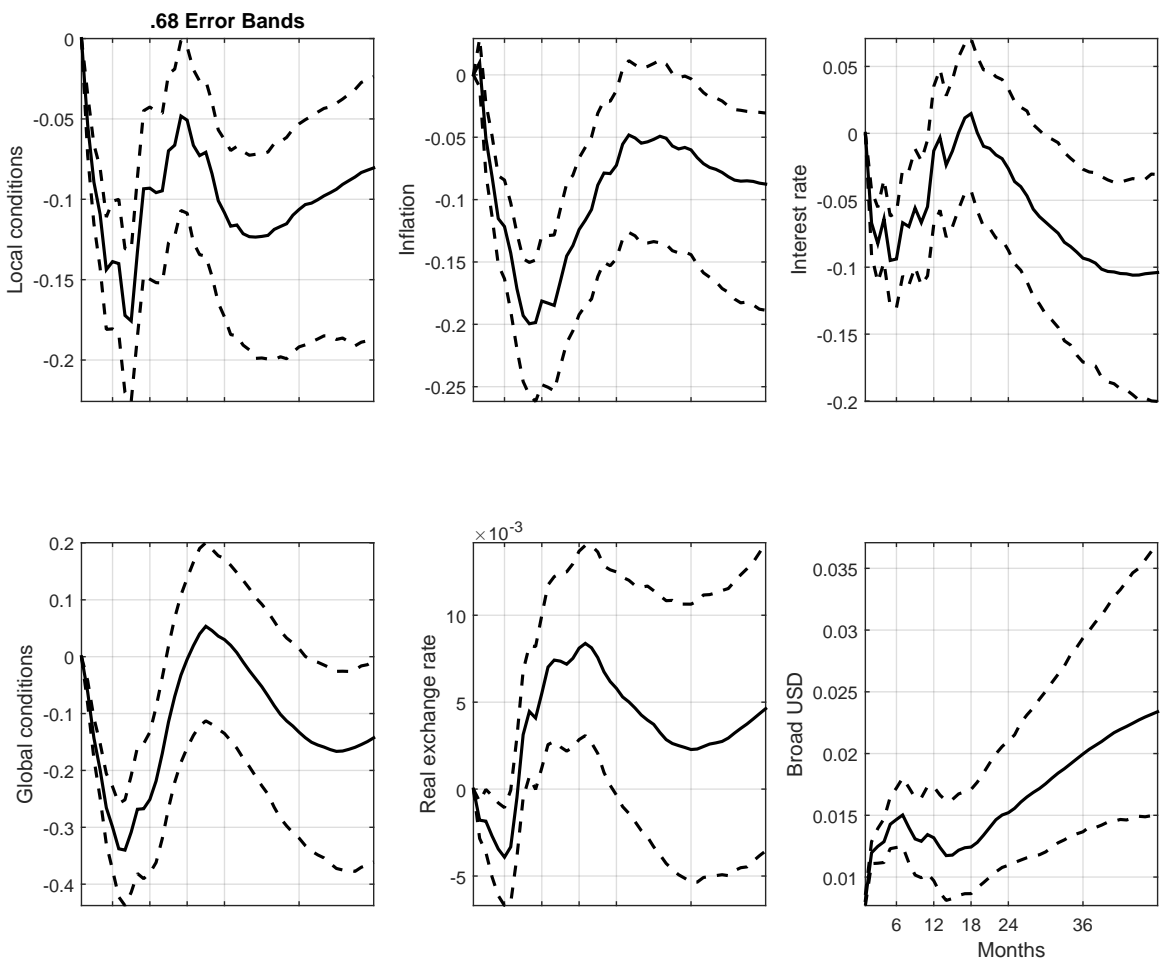

FiguRE 4. Impulse responses to a positive shock to the broad dollar index in the benchmark FAVAR model for Korea. The solid lines represent the median impulse responses. The dashed lines indicate the $68 \%$ confidence bands. 

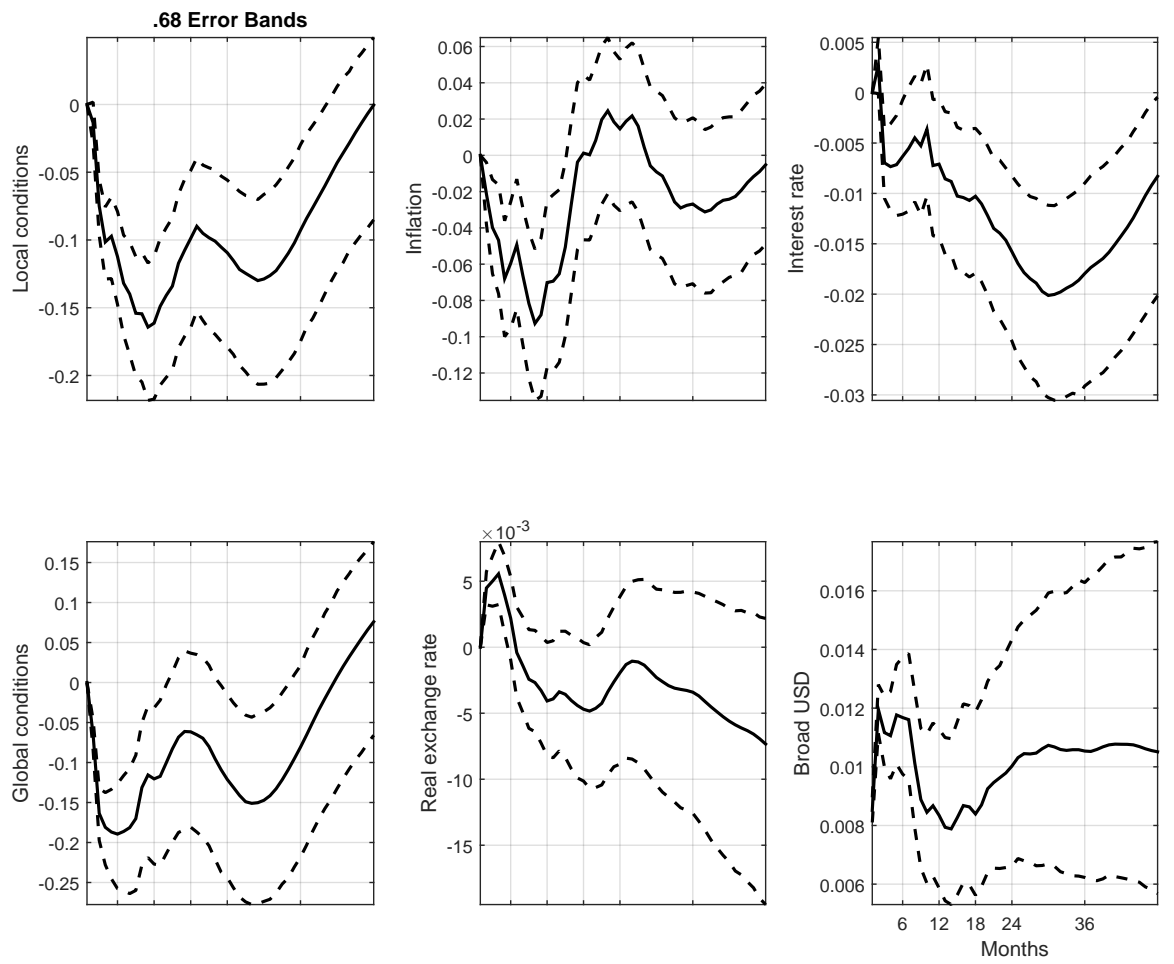

FiguRE 5. Impulse responses to a positive shock to the broad dollar index in the benchmark FAVAR model for Japan. The solid lines represent the median impulse responses. The dashed lines indicate the $68 \%$ confidence bands. 

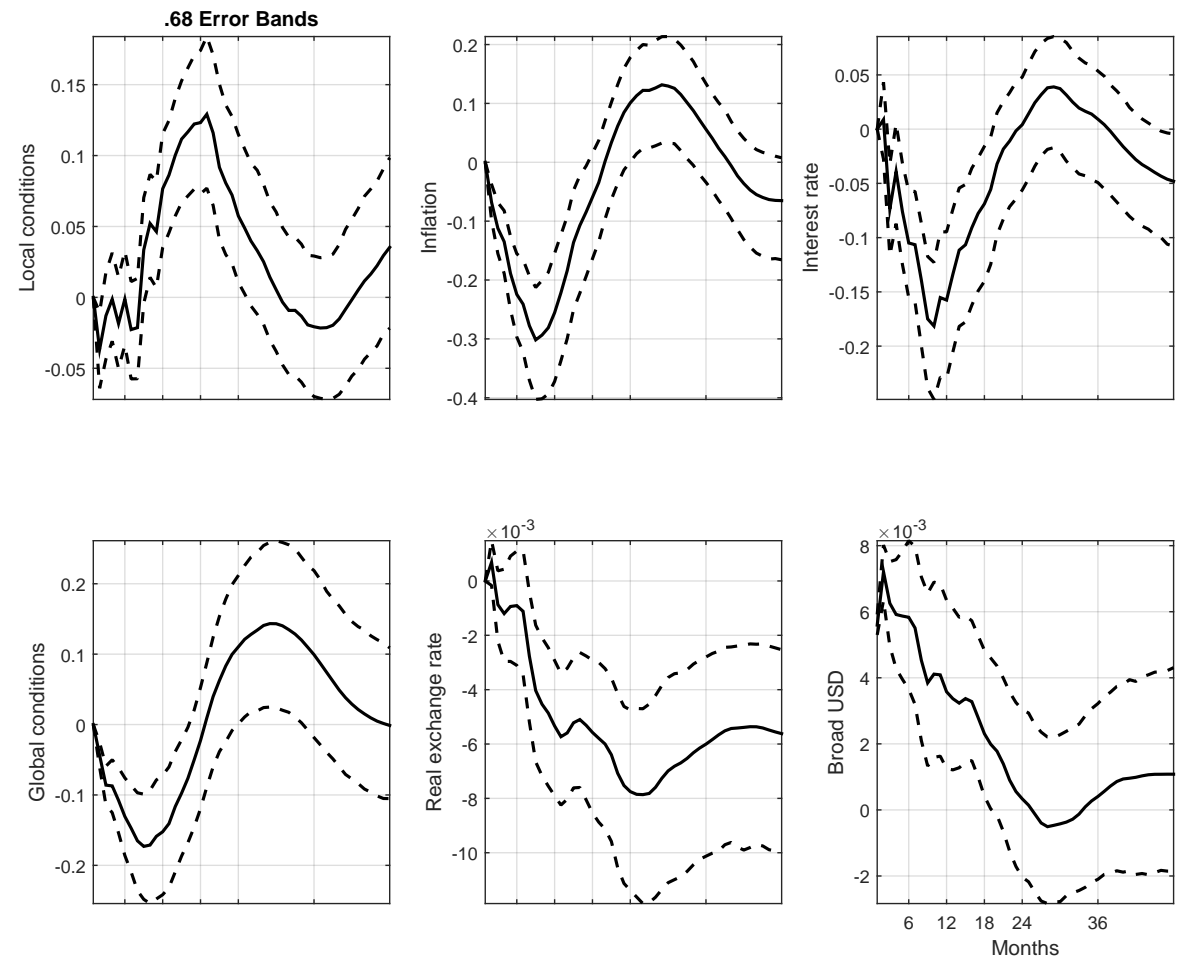

FiguRE 6. Impulse responses to a positive shock to the broad dollar index in the benchmark FAVAR model for China. The solid lines represent the median impulse responses. The dashed lines indicate the $68 \%$ confidence bands. 

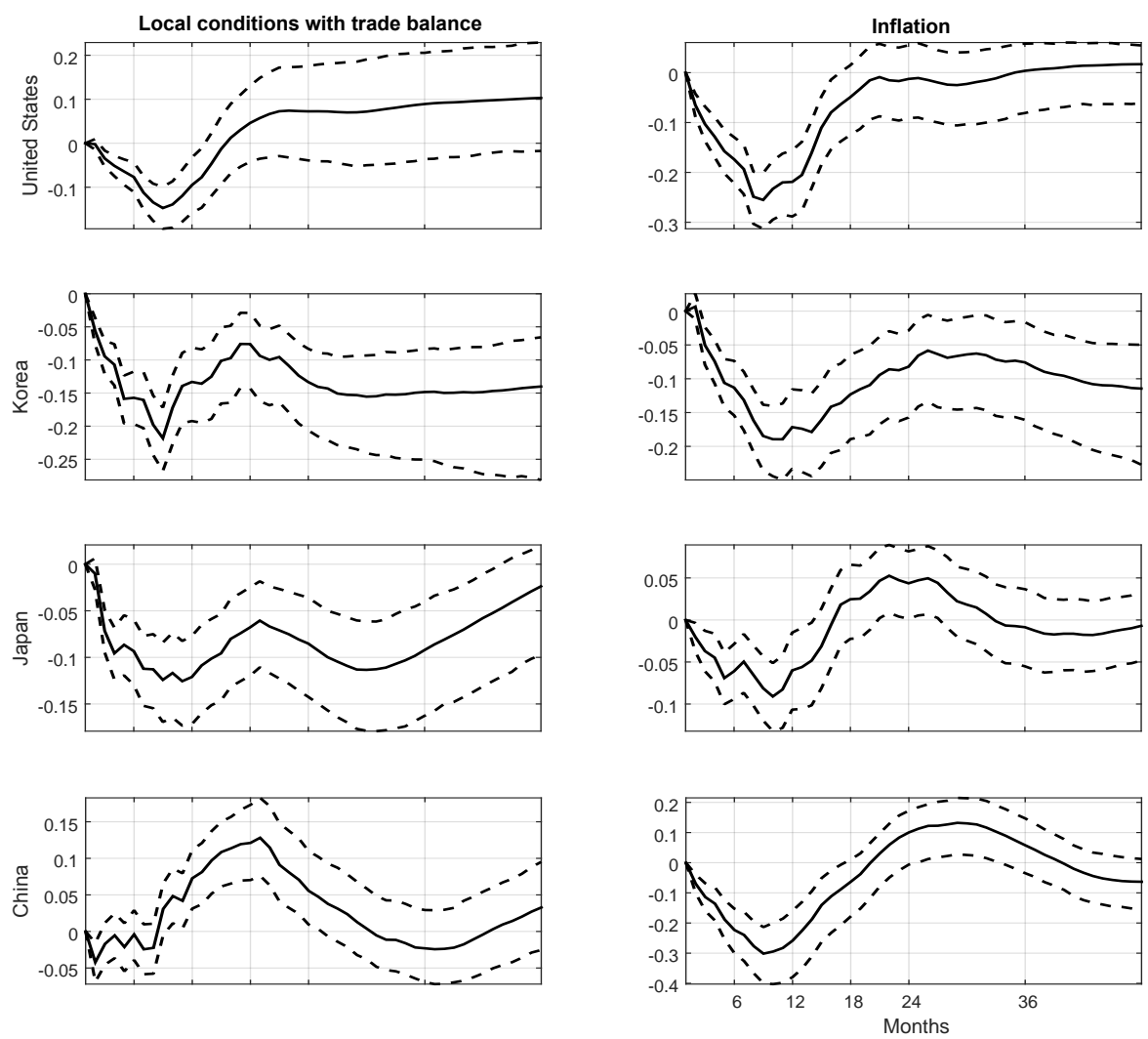

Figure 7. Impulse responses to a positive shock to the broad dollar index in the FAVAR model for US, Korea, Japan and China, with an alternative measure of local conditions that include trade balances as an observable factor. The solid lines represent the median impulse responses. The dashed lines indicate the $68 \%$ confidence bands. 

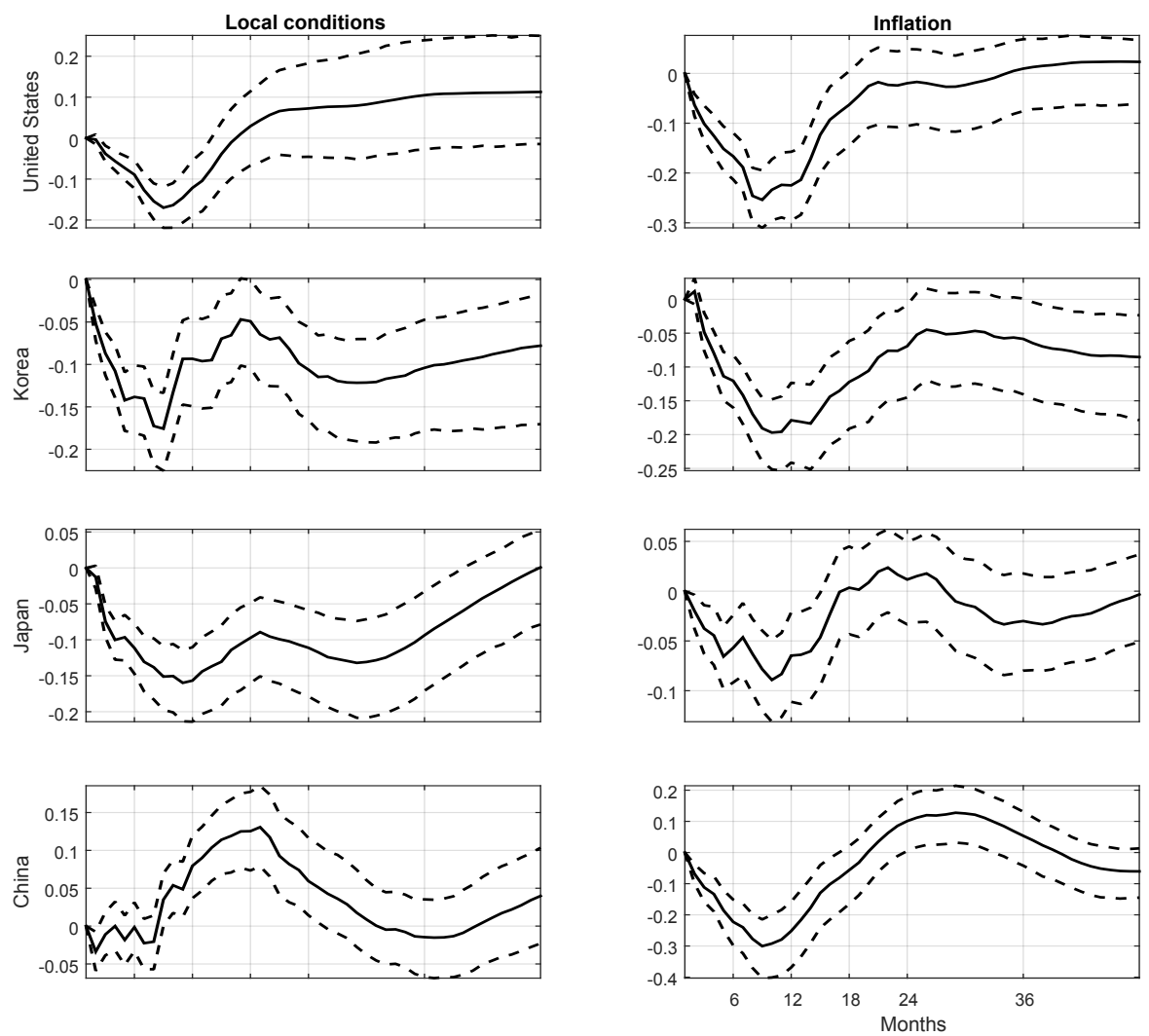

FiguRE 8. Impulse responses to a positive shock to the broad dollar index in the FAVAR model for US, Korea, Japan and China, with an alternative measure of global activity indicator that excludes oil prices. The solid lines represent the median impulse responses. The dashed lines indicate the $68 \%$ confidence bands. 

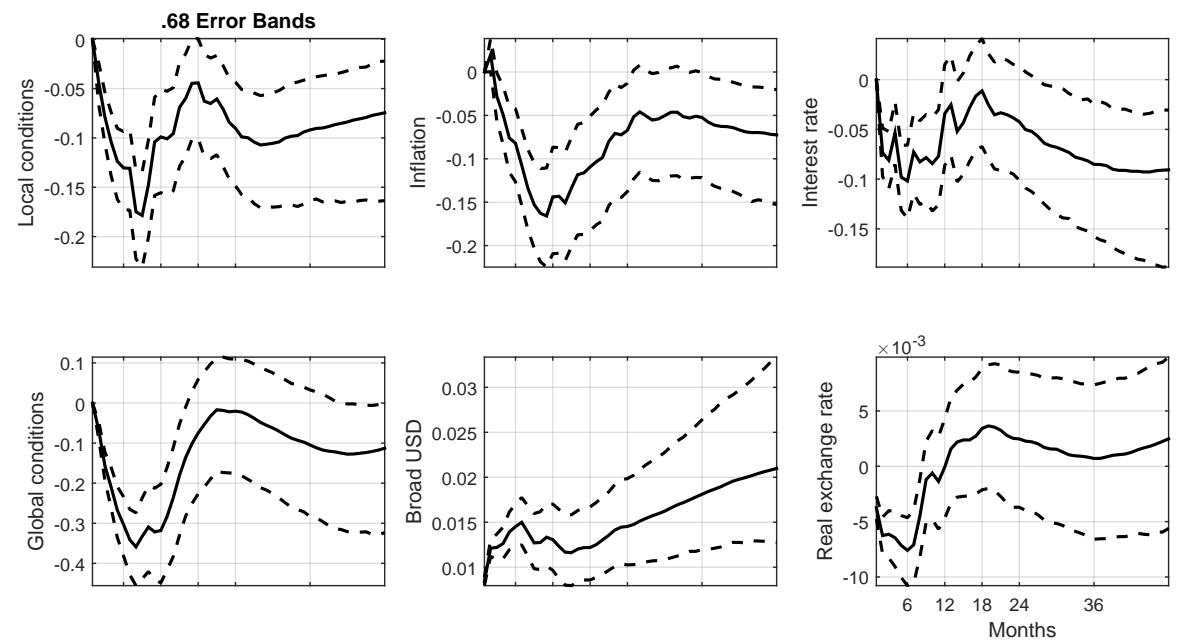

Figure 9. Impulse responses to a positive shock to the broad dollar index in an alternative FAVAR model for Korea, with the real effective exchange rate ordered last. The solid lines represent the median impulse responses. The dashed lines indicate the $68 \%$ confidence bands. 

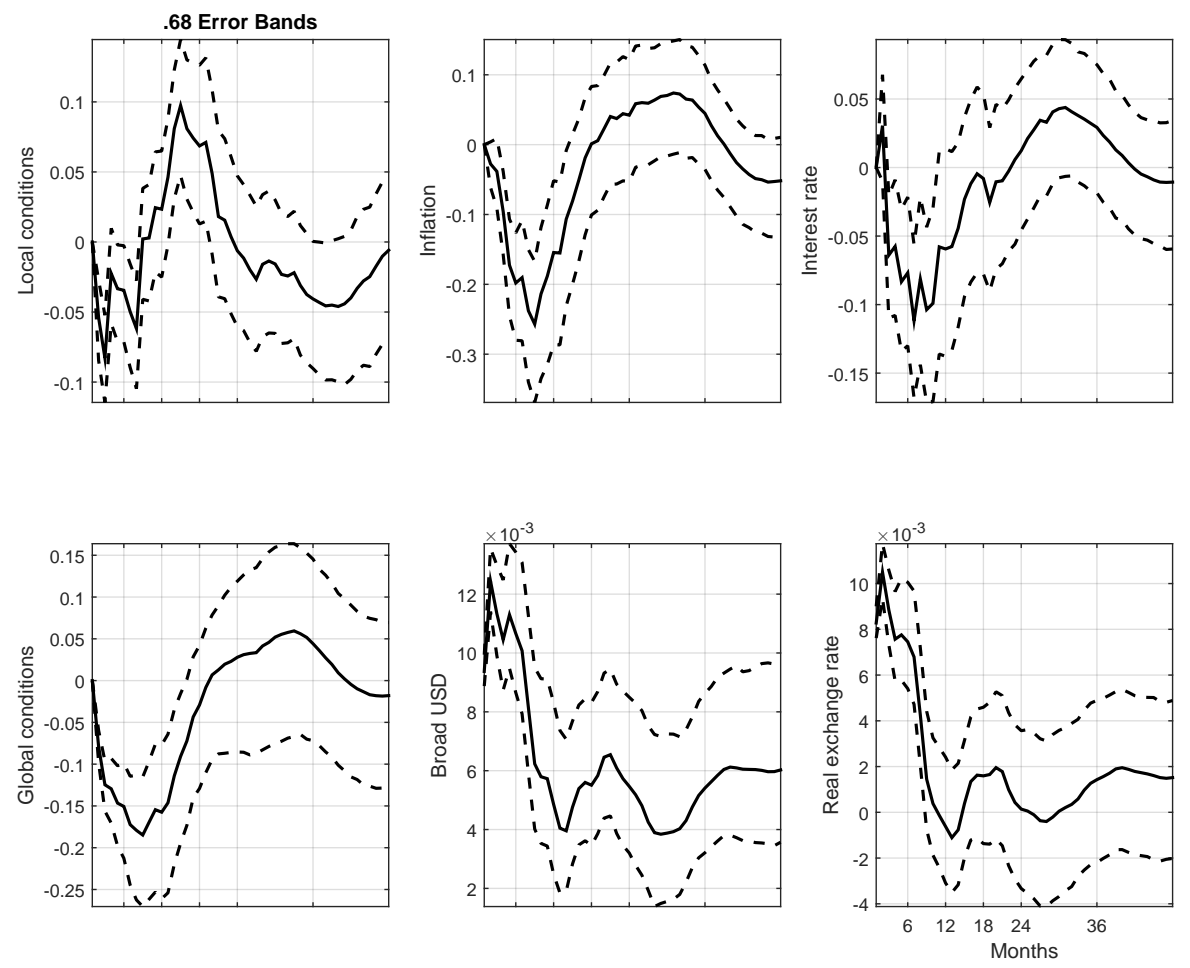

Figure 10. Impulse responses to a positive shock to the broad dollar index in an alternative FAVAR model for China, with the real effective exchange rate ordered last. The solid lines represent the median impulse responses. The dashed lines indicate the $68 \%$ confidence bands. 

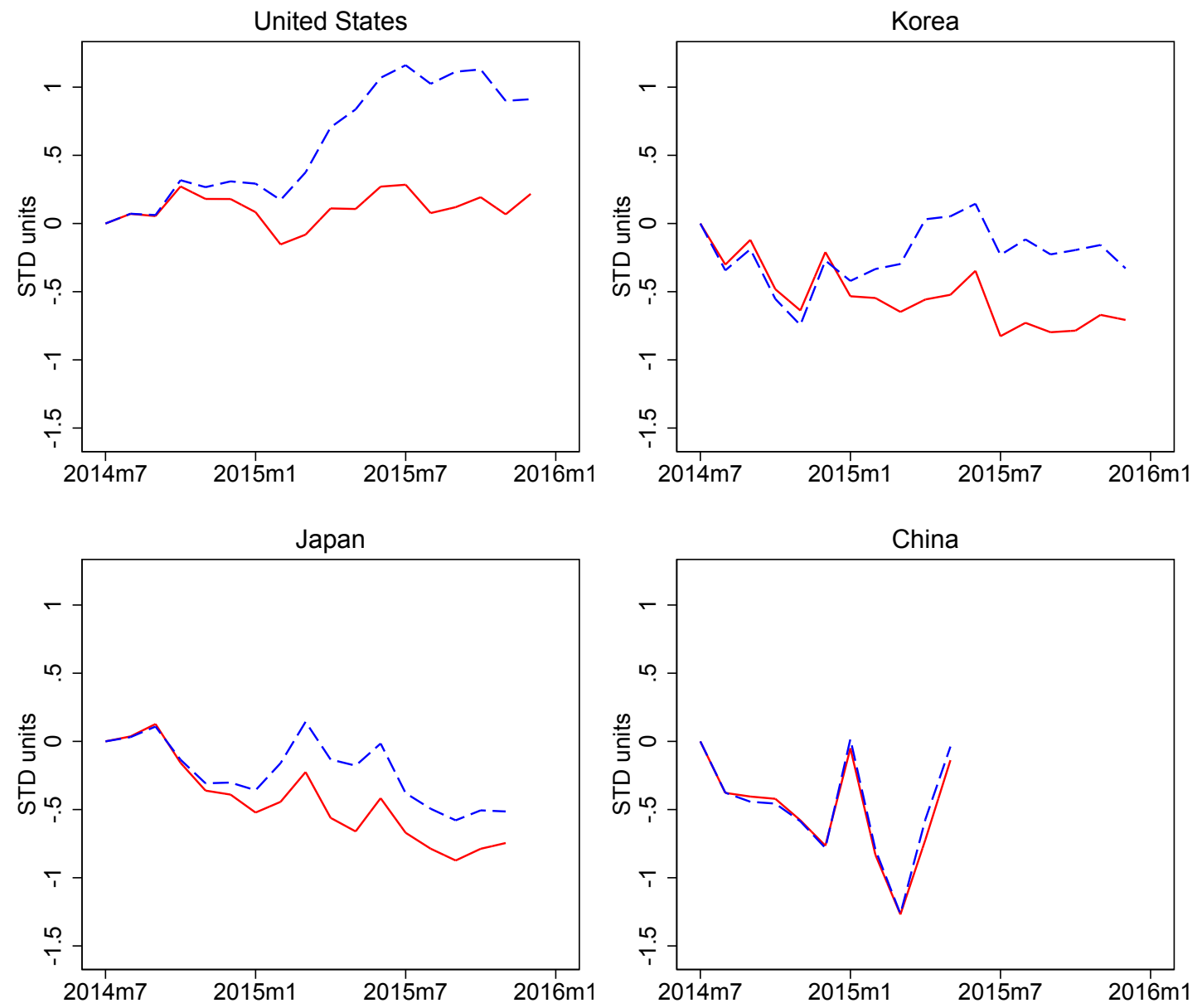

- Actual - - Counterfactual

Figure 11. The actual path of local conditions index (the solid line) versus the counterfactual path (the dashed line), the latter of which is calculated from the estimated FAVAR model but imposing the assumption that the broad dollar index in July 2014 through the end of the sample remained unchanged at its June 2014 level. 

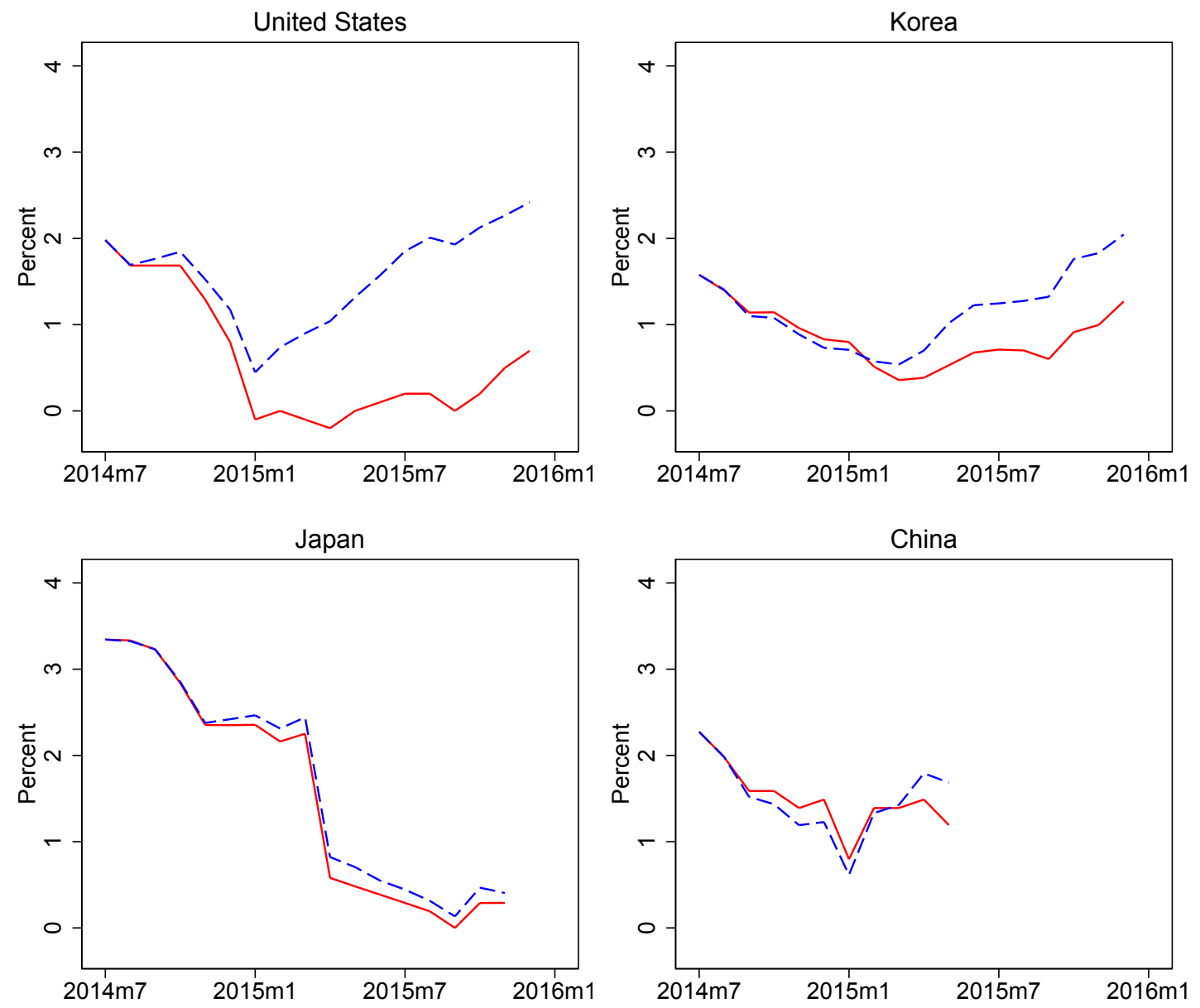

- Actual --- Counterfactual

Figure 12. The actual path of inflation (the solid line) versus the counterfactual path (the dashed line), the latter of which is calculated from the estimated FAVAR model but imposing the assumption that the broad dollar index in July 2014 through the end of the sample remained unchanged at its June 2014 level.

Federal Reserve Bank of San Francisco 